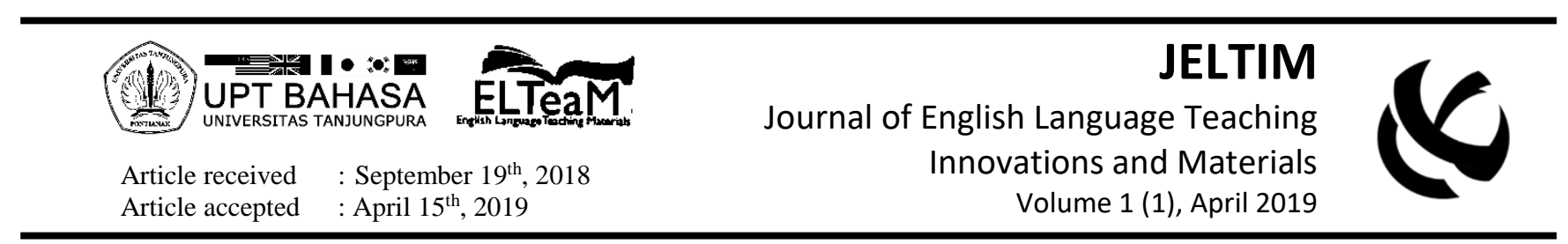

\title{
THE ROLE OF MOTIVATION IN LEARNING ENGLISH AS A FOREIGN LANGUAGE
}

\author{
Dwi Riyanti \\ English Study Program of FKIP, Universitas Tanjungpura, Indonesia \\ dw_riyanti@yahoo.com
}

\begin{abstract}
Motivation is undoubtedly an important factor in learning foreign languages. Yet, in English as foreign language context, like Indonesia, especially in West Kalimantan, not all students are motivated to learn English even though it is a compulsory foreign language for secondary students. Thus, it is very important for teachers to know how to increase students' motivation. This paper explores the issue of motivation in learning English in a foreign language context, which can be useful for teachers and students to know why motivation is important in learning foreign languages. Through reviewing related literature to motivation, this paper outlines the role of motivation in learning a foreign language and the problems of low motivation commonly found in EFL contexts. It also discusses some possible causes of low motivation as well as elaborates ways that teachers can do to increase students' motivation.
\end{abstract}

\section{Keywords}

role of motivation, motivational strategies, teacher's role

\section{INTRODUCTION}

The notion that motivation plays an important role in second or foreign language learning is unarguable. It is widely known that students with high motivation are likely to be more successful in their language learning (Dornyei \& Csizer, 1998). Even though the importance of motivation is well known, not all students have high motivation to learn foreign languages. In junior and senior high schools within Indonesian contexts, for example, many students still think that English is difficult subject, and they seem unmotivated to learn English in the classrooms.

As a compulsory subject at junior and senior high schools, all students at these levels must take English subject from the first year they enter the schools until they graduate. So, by the time the students finish their study in senior high schools, they have been learning English for at least six years. Therefore, It is expected that their command of English is sufficient to be able to communicate in English. Ironically however, many students still have problems with English as they enter university for continuing their study. Even though it cannot be generalized that their lack of command in English is because of their low motivation, this suggests that students' motivation contributes to the students' competence in English. A Study by Midraj et el. (2008) on the relationship between motivation and students' achievement indicates positive correlation in which students with high motivation tend to have better achievement in learning English.

Considering that low motivation can be one of the sources of students' low achievement in learning English, this paper aims at providing an overview of the role of motivation in improving student's ability in English. This overview may be used as a source of reflection for teachers as well as for students to be aware of the importance of motivation. Specifically, this paper identifies the sources of low motivation and explores ways that language teachers can do to increase students' level of motivation where English is learnt as a foreign language and as a compulsory subject.

\section{THE IMPORTANCE OF MOTIVATION IN FOREIGN LANGUAGE LEARNING}

The term motivation at the basic level, according to Harmer (2007, p. 98), means "some kind of internal drive which pushes someone to do things in order to achieve something". Additionally, Winke (2005, p. 4) argues that motivation refers to Gardner's model of a socio educational model of 
language acquisition. In this model, motivation to learn a foreign language is described as "a complex of construct, involving effort and desire, as well as a favourable attitude toward learning the language at hand" (Gardner, 1985 cited in Winke, 2005, p.4). This can mean that motivation to learn a foreign language is different from other types of motivation.

In terms of motivation categorization, Dörnyei (1994, p. 275) argues that one of the most general and well-known distinctive features of motivation theories is that "motivation can be categorized into intrinsic and extrinsic motivation". This classification according to Noels, et al. (2003) is based on self-determinant theory. In that theory, intrinsic motivation refers to "motivation to engage in an activity because that activity is enjoyable and satisfying to do" (Noels et al., 2003, p. 38). From the theory, it can be concluded that intrinsic motivation comes from inner side of individual learners. Meanwhile, extrinsic motivation comes from external sides of the learners. The extrinsic motivation that can be in forms of money, prizes, grades, and even punishment (Brown, 2007). In general, both extrinsic and intrinsic motivation are crucial in the success of learners in all levels of their education (Susanto, 2018).

In second or foreign language learning, motivation is one of the important factors that contributes to the success of learning languages (Dornyei \& Csizer, 1998). Additionally, Wang (2006, p. 32) says that "motivation is an important affective variable in second language acquisition and it has correlation with second language achievement and proficiency". This indicates that even though motivation is not the only factor which contributes to the achievement of the language, it is a crucial factor in learning a language. Similarly, Dörnyei (1994, p. 273) argues that motivation is "one of determinants of second or foreign language learning achievement". From Wang's and Dörnyei's point of views, it is clear that motivation is an important factor in language learning and influences students' achievement in their second or foreign language learning.

\section{SOME CAUSES OF LOW MOTIVATION IN LEARNING ENGLISH}

In a foreign language teaching and learning context, the problems of low motivation are commonly found. For example, in an English classroom, many students do not seem to show enthusiasm in their English classrooms. They just sit on their desks and do the activities that their language teachers instruct them to do with hesitance.
Some of them even just copy their friends' work. Many of them often sleep in the class while teaching and learning are taking place. These can be some of the indicators that the students have problems with their motivation to learn English even though it can also be triggered by some other reasons.

The causes of low motivation can be very complex depending on the contexts of English language teaching. For example, the causes of motivation problems to learn English in countries like Japan and Indonesia may be different although in both countries English is taught and learnt as a foreign language. Even within Indonesian context of English language teaching, the motivation problem is not necessarily the same. The causes of low motivation in private schools where there are adequate facilities to learn English and state schools in country sides or small towns where facilities are inadequate may not be the same as well. Even the problem of motivation in a foreign language classroom in the same school can also be different. In a class where many of the students take English courses outside the school hours, the students may be more motivated compared to other classes where many of the students never join any English courses before. Thus, identifying the sources of problems in students' low motivation is important before deciding ways to increase students' level of motivation.

In Indonesian context, for example, English is considered as an important foreign language that is taught to junior and senior high school students as a compulsory subject. As a compulsory subject at schools, students have to learn English even though they do not have willingness to learn the language. This situation may contribute to the students' low motivation because the students may feel that they are forced to learn. As a result, they learn English without having strong commitment. The other reason could be related to the availability of the teaching learning facilities. For instance, when the students want to improve their listening in English but there is no facility to support the learning, the students may feel unmotivated. Other possible reason could be the lack of qualified English teachers and English materials. In this context, the students may get bored with the ways that the English teachers teach them or they get bored with the monotonous materials that the teachers provide for the students. One of the consequences for not having qualified teachers and adequate materials is that students can extrinsically unmotivated. In addition, students may also feel unmotivated to learn English since they cannot see the importance of English outside the classroom. Once they leave the classroom, they are not exposed to the use of English. Facing this situation, students may think 
that learning English is something that is not worthdoing, and this can lead to the students' low motivation.

In relation to the situation where English is learnt as a compulsory subject in a foreign language context, many students are motivated to learn English because of external factors. The findings of a research on orientations as a part of motivation, show that many students from Asian countries such as Indonesia, Thailand, have instrumental orientations in which "students see the importance of learning English for job-related purposes" (Bradford, 2008, p.312). The findings of the research imply that students in the countries where English is learnt as a foreign language tend to be extrinsically motivated.

\section{WAYS TO INCREASE STUDENTS' MOTIVATION LEVEL TO LEARN ENGLISH}

Increasing the level of students' motivation in learning English as a foreign language has become one of the goals of English language teaching in Indonesia. At country level, for example, the government decides to make English as a compulsory subject at schools. This can be viewed as one of the efforts to increase students' motivation to learn English (Winke, 2005). However, since increasing students' motivation is a complex process involving many aspects such as students' interest and their economic and social backgrounds, teachers, as well as educational institutions, deciding English as a compulsory subject only is not enough. Therefore, involving all educational stake holders is very important, particularly language teachers as key people who are very close to the students.

In Indonesian contexts, for example, since English is mostly learnt in the English classrooms, English teachers have important roles to increase students' motivation. In the classroom, according to Dörnyei (2001), teachers can encourage students' motivation to learn English in various ways by using motivational strategies. Further, Dörnyei (2001) provides a framework for motivational teaching practice that consists of four main dimensions. The first dimension is creating the basic motivational conditions. This dimension is very important as a starting point to increase students' motivation particularly in the classroom where in general students are mostly unmotivated. The second one is generating initial students' motivation. After the basic condition for motivation has been established, teachers need to use strategies to build up students' initial motivation. The third dimension is maintaining and protecting motivation. This is the next step to preserve students' motivation in learning. The fourth dimension is encouraging positive retrospective self evaluation. It is a kind of reviewing whether the strategies used are useful or need to be changed.

\subsection{Creating Basic motivational conditions}

Teachers need to consider the first step of motivating students to learn which is creating basic motivational conditions. According to Dörnyei (2003), this step is very important as a foundation for encouraging students' motivation and could consist of warm up activities in the classroom. In this step, teachers condition students to be ready to learn and to be able to increase their awareness about the importance of motivation. For example, in reading classes, teachers can do warm up activities such as asking questions related to students' prior knowledge to the reading topics rather than directly ask students to read texts.

Another way to create a basic motivational condition according to Dörnyei (2001, p. 120) is by showing "appropriate behaviour and having good relationship with students". If the teachers are friendly and enthusiastic, the students tend to like the subjects that those particular teachers teach. Stressing on the importance of the teachers being enthusiastic, Davis (1993) argues that an instructor's enthusiasm is a crucial factor in students' motivation. If the teachers become bored, typically the students will be bored too. Relating to teachers' behaviours, according to Dörnyei (1994, p. 282), there are three basic characteristics of teachers that enhance learning. They are emphatic, congruent and accepting. Emphatic teachers are usually sensitive to students' need and feelings. Congruence here refers to the ability to behave as natural as possible. Accepting means teachers acknowledge that each student is a complex human being with both virtues and faults. Similar to teachers' behaviours, teachers' relationship with the students also influences students' motivation to learn. If teachers have good rapport with the students, the students usually feel motivated when those teachers teach them. Additionally, Harmer (2007, p. 100) argues that "when students feel that the teacher has little interest in them, they will have little incentive to remain motivated". It implies that in order to motivate students, teachers also need to be responsive to students' interest. Normally, if teachers have good rapport with students, both teachers and students can enjoy doing activities in the classroom. This can certainly increase students' level of motivation.

The third way to create basic motivational conditions is by creating pleasant and supportive classroom atmosphere in which students can feel comfortable and relaxed being in the classroom. 
This, according to Dörnyei (2001, p. 42) can be done by establishing a norm of tolerance among students. For example, by involving students to set classroom rules so that they can feel that the class is theirs and they need to be responsible for what they agree on. As parts of creating comfortable atmosphere, teachers also need to encourage students to take a risk in their learning in which mistakes are viewed as a natural process of learning rather than a sign of weaknesses. By doing that, students are not afraid of making mistakes since mistakes are common things in learning. In the comfortable classroom where students can feel secured, students may not feel reluctant to participate in the language activities, which can gradually increase their motivation as well. Additionally, Dörnyei (2001) mentions that in order to make pleasant atmosphere in the classroom, teachers can create humour so that students can feel that English classroom is not threatening. Humour is also good to be used as an ice breaker so that students can feel relaxed and less stressful even when they are doing difficult tasks. However, teachers need to be aware that humour may cause embarrassment for students. For example, using students' mistake to create humour can make students who make the mistakes feel demotivated to learn as they think the teachers do not respect the students. Therefore, choosing suitable humour is crucial in maintaining comfortable atmosphere in the classroom.

\subsection{Generating students' initial motivation}

Once the basic motivational conditions have been created, teachers need to generate students' initial motivation as the next step to increase students' motivation. The first way to generate initial motivation according to Dörnyei $(2001$, p. 124$)$ is by "enhancing the learner's language-related values and attitudes". Since values and attitudes have positive correlation to the motivation, teachers need to be able to promote positive value of learning English. Teachers can do this by reiterating the role of English in the world and giving examples of the benefits of being able to communicate in English such as in relation to the global trade and being able to travel to English speaking countries.

The second way to generate initial motivation is by "increasing the learners' goal-orientedness" (Dörnyei, 2001, p. 125). This may be rather difficult for students who learn English just because it is a compulsory subject at schools like in Indonesian contexts. Accordingly, teachers need to help students formulate their goals in learning English since not all students understand the reasons why they learn English. Dörnyei (2001, p. 125) argues that "the most obvious way to help students in determining their oriented goals is to initiate discussion with students". In this discussion, teachers need to be able to accommodate what their goals are and be able to relate with the importance of learning English. Once students are able to identify their goals, they may see the purpose of their learning and gradually their motivation is likely to increase.

Another way to generate initial motivation is by "making the teaching materials relevant to students' needs" (Dörnyei, 2003, p. 24). For example, if the students need to learn English only for passing examination, then the materials should be related to their need for the examination. However, in order to increase students' motivation in learning English other than only for the sake of examination, language teachers can go a step further by promoting one activity at a time that relates to students' involvement. For example, in promoting other English skill such as improving speaking ability and other oral skills, teachers can allocate several minutes in each class meeting to have activities that promote oral language production. With this kind of involvement, students can feel that learning English is not only a matter of passing examination. This strategy can also help students to set their long-term motivation which can result in the increase of their motivation level.

\subsection{Maintaining and protecting motivation}

As soon as initial motivation can be generated, teachers need to be able to maintain and protect their students' motivation. Otherwise, the students' motivation will last within a short period of time. One of the ways to do this is by "making language classes interesting" (Dörnyei, 2001, p. 138). This is very important especially for the English classroom in which English is learnt as a foreign language. Uninteresting classroom activities may bore students easily. In accordance with Dörnyei (2001), Holt (2001) suggests that one of the ways to increase students' motivation in learning English is that "teachers need to create interesting lessons in which students' attention is gained" (p.1). In this case, the role of English teachers is very crucial in choosing lessons to be taught and in selecting the media to be used in the classrooms.

As part of creating interesting lessons, teachers need to be able to select materials that are of students' interests. For example, if the students are teenagers, then the materials should be related to their world. In doing this, teachers need to be creative in adjusting materials from text books and in adding some supplementary materials from other sources such as from internet, youth magazine and other authentic materials.

Since the concept of interesting could vary from student to student, teachers may need to negotiate 
with students first. It can be done at the beginning of semester or at the first meeting of the class. Besides that, to avoid boredom in class, teachers also need to vary the tasks in English classroom. Dörnyei (2001) suggests some ideas to create motivating tasks, one of which is that "the tasks should be challenging in which students need to solve problems, discover something, overcome obstacles, avoid traps and find hidden information" (pp. 75-76). Even though the tasks appear to be perfect for the learners, language teachers need to consider the level of students. Otherwise, the students will be unmotivated because the tasks are too difficult for them.

In relation to providing motivating tasks, teachers need to be aware that they need to present the tasks clearly by giving clear directions, providing guidance about how to do the task, and stating the purpose and utility of every task. Commonly, students will be able to do the tasks easier and quicker if they know what is required and how to do the tasks. Since students in English as a foreign language context usually have limited command of English, teachers need to give instructions which are as clear as possible. Therefore, clear instruction is very crucial in helping students to do the tasks and encourage them to be more motivated. Another way to maintain and protect motivation is by "promoting learner autonomy" (Dörnyei, 2001, p. 131). As classroom meeting is limited by the time, teachers need to encourage students to be independent in learning. This can be done by teaching them how to continue learning outside the classroom.

\subsection{Encouraging positive retrospective self evaluation}

The last dimension of motivational teaching practice, which is also known as post-actional stage in motivating students is related to self evaluation from both teachers and students themselves. The purpose of this stage is to know whether the motivational strategies used are useful for students or not. According to Dörnyei (2001) this can also be used for students to evaluate things that have helped them to achieve their goal of learning and determine types of motivational activities that they will pursuit next. One of things that teachers can do at this stage is providing motivational feedback (Dörnyei, 2001).

Despite the powerful four motivational dimensions proposed by Dornyei (2001), additional ways of motivating students may still be needed. Since students' motivation is influenced by many factors that can be different from one student to another, there is no magic way to increase student motivation (Davis, 1993). For example, some students will be motivated by the approval of others, while some other students may be motivated by overcoming challenges. Thus, language teachers need to use various ways to increase students' motivation not just refer to the four domains of motivational strategies.

According to Davis (1993), there are several general strategies that teachers in the classroom can use to increase students' motivation. One of the general strategies to motivate students is that the teachers need to be aware of students' existing needs. One reason for this is that students usually learn best when they feel that they get what they want from the subject. For example, in junior and senior high school where students take English class because English is compulsory subject and there will be final examination for the subject, students will be more motivated if they can recognise why they need to learn the subject and the importance of having the ability of English for their future needs. In this case, the teacher needs to always remind the students what they are learning is useful for their future not just because they have to do the examination. Besides relating to the students' need in general, teachers also need to be aware of the students' immediate needs to complete a particular task or activity in the class. In this case, teachers need to respond not only to the need to complete the tasks prescribed in the syllabus but also their needs in using English in their real life. Satisfying such needs is rewarding for the students, and such rewards sustain learning more effectively than just considerations about their grades (Davis, 1993).

Another motivational behavior that Davis (1993) sugests is encouraging students as active participants in learning. This is because students learn in many ways, for example, by doing, making, writing, designing, creating, and solving. In this case, teachers need to give opportunities for the students to think first before giving the expected answers. For example, teachers should not tell students something when they can ask other students. Another example is that teachers need to encourage students to work in small groups rather than work individually. It is because group work encourages students to share their work and learn from each other.

Apart from using motivational strategies, teachers in the classroom can also set up motivational behaviours. According to Davis (1993), one motivational behaviour that teachers can encourage is setting realistic expectations from their students. It is because a teacher's expectations have a powerful effect on a student's performance. If a teacher acts as though he or she expects his/her students to be motivated, hardworking, and interested in the course, the students are more likely to be so. Another motivational behaviour that a teacher can promote is that teachers can help students to set achievable goals for 
themselves. Failure to attain unrealistic goals can disappoint and frustrate students, and this is not good for maintaining students' motivation. Because of that, teachers need to encourage students to focus on their continued improvement, not just on their grade in any test or assignment. The next motivational behavior is that teachers need to tell students what they need to do to succeed in the course. In this context, teachers need to mention clearly what their students need to do to pass the course. Teachers should not let students struggle to figure out what is expected from them.

Furthermore, Davis (1993) argues that to maintain students' motivation, teachers also need to strengthen students' self-motivation. One way to do this is by avoiding messages that reinforce teachers' power as instructors or that emphasize extrinsic rewards. Another strategy is to avoid intense competition among students. This is because competition produces anxiety, which can interfere with learning and lead students to be unmotivated.

\section{CONCLUSION}

Drawing on Dörnyei's (2001) framework, and related work on motivation issues in the context of foreign language teaching and learning, it can be concluded that motivation is very important in learning English. As part of the efforts to increase students' level of motivation in situations where English is learnt as a foreign language and a compulsory subject at schools, language teachers can use motivational strategies in the classroom. The four dimensions of motivational strategies can be powerful to increase students' motivation as they provide steps to be done by teachers. The steps consist of creating motivational conditions as a prestage in motivating students, generating initial motivation, maintaining and protecting motivation as well as evaluating whether the strategies work or not.

Finally, since English classroom conditions and learners could vary from place to place, the way to motivate students may also be different. Therefore, the motivational strategies cannot be used as a generalization that can be applied in any English classroom contexts. Nevertheless, understanding motivational strategies is very important for English teachers in order to be able to motivate their students to learn a foreign language, particularly English language.

\section{REFERENCES}

Bradford, A. (2007). Motivational Orientations in Under-Research FLL contexts: Findings from Indonesia. SAGE Publication. Accessed via www.RELC.sagepub.com on 20/10/08.

Brown, H. D. (2007). Teaching by Principles: An Interactive Approach to Language Pedagogy. New York: Pearson Education.

Davis, B. G. (1993). Tools for teaching. San Francisco: Jossey-Bass Publishers.

Dörnyei, Z. (1994). Motivation and Motivating in the Foreign Language Classroom. The Modern Language Journal, 78(3), 273-284.

Dörnyei, Z. (2001). Motivational Strategies in the Language Classroom. Cambridge: Cambridge University Press.

Dörnyei, Z. (2001). Teaching and Researching Motivation. Harlow: Pearson Education.

Dörnyei, Z. (2003). Attitudes, Orientations, and Motivation in language learning: Advances in Theory, Research, and Applications. in Dörnyei, Z. (Ed.). Attitudes, Orientations, and Motivation in language learning. (pp, 3-32). Malden: Blackwell Publishing.

Dornyei, Z., \& Csizer,K. (1998). Ten commandments for motivating language learners: results of an empirical study. Language Teaching Research 2(3), 203-229.

Harmer, J. (2007). The Practice of English Language Teaching (4 ${ }^{\text {th }}$ edition). Harlow: Pearson Education.

Holt, J.N. (2001). Motivation as a Contributing Factor in Second Language Acquisition. The Internet TESL Journal, 7(6). Accessed via www.teslj.org on 1/11/08.

Midraj, S. et al. (2008). The Affective Factors and English Language Attainment of Arab EFL Learners. International Journal of Applied Educational Studies, 1(1), 43-52.

Noels, K.A., Pelletier, L.G., Clement, R., \& Vallerand, R. J. (2003). Why are you Learning a second language? Motivational Orientations and self-determination theory in Dörnyei, Z. (Ed). Attitudes, Orientations, and Motivation in language learning. (pp, 33-63). Malden: Blackwell Publishing. 
Susanto, A. (2018). The important role of motivation in foreign language learning: A review. Jurnal Pendidikan Unsika, 6(1), 50-59.

Wang, Y. (2006). The factors in L2 Learning and Motivation and Their Pedagogical Implications in English Classroom. Sino-English Teaching, 3(7), 32-38.

Winke, P.M. (2005). Promoting motivation in the foreign language classroom. CLEAR News, 9(2), $1-9$. 
